\title{
The Thyrotropic Cell of the Rat Hypophysis as Studied with Peroxidase-labeled Antibody'
}

\author{
BURTON L. BAKER AND YA-YEN YU \\ Department of Anatomy, The University of Michigan Medical School \\ Ann Arbor, Michigan 48104
}

\begin{abstract}
Utilizing the peroxidase-labeled antibody procedure with antiserum to human thyrotropin (anti-TSH), the thyrotropic cell was studied in the rat hypophysis with respect to its cytology, distribution, and reactivity to histochemical stains. The presumptive thyrotropic cells were polygonal and stained with aldehyde fuchsin and the periodic acid-Schiff procedure. They were usually located centrally in cell cords. In the pars distalis thyrotropic cells were most numerous in the centromedian area of the lateral lobes and beneath the pars intermedia, while being rare in the dorsocephalic region.

Several steps were taken to verify the specificity of the immunochemical procedure. After absorption with either human or bovine thyrotropin, anti-TSH was completely ineffective; staining was almost completely prevented by prior absorption with either sheep or rat thyrotropin. Cytological alterations in thyrotropic cells generally paralleled the differences in pituitary thyrotropic content associated with sex, thyroid deficiency, thyroxine administration, and with rebound after cessation of treatment with propylthiouracil. Thyrotropic cells were differentiated from growth hormone, prolactin and corticotropic cells, as well as from presumptive luteinizing hormone cells, on the basis of shape, cytology, intraglandular distribution, and by immunochemical double-staining. In this study they were not distinguished from follicle-stimulating hormone cells which remain unidentified in this laboratory.

Our observations confirm those of earlier investigators, who used histochemical methods for identification of the thyrotropic cell, with regard to its cytological features, intraglandular distribution and responsivity to altered levels of circulating thyroid hormone.
\end{abstract}

Conclusive identification of the thyrotropic cell in the rat, and differentiation of it from all other pituitary cell types, have not yet been achieved. When studied with the light microscope, much cytological and experimental evidence indicates that the thyrotropic cell of the rat pituitary gland is polyhedral and that its cytoplasm stains with aldehyde fuchsin as well as the periodic acid-Schiff (PAS) procedure (Purves and Griesbach, '51a,b,c; Halmi, '50, 52; D'Angelo, '63). However, since the corticotropic cell also appears to be aldehyde fuchsin-positive (Halmi, '50; Baker et al., '70), additional evidence is needed to ascertain if thyrotropin and corticotropin are produced by the same cell as has been claimed (Dhom, '63). Further, the cellular origin (s) of follicle-stimulating (FSH) and luteinizing ( $\mathrm{LH}$ ) hormones is still under investigation and the relationship of the thyrotropic cell to these cells merits additional consideration because the three hormones are glycoproteins with some structural similarities. Finally, our understanding of the cytological response of the thyrotropic cell to hypothyroidism remains uncertain (D'Angelo, '63; Goluboff, '70).

At the ultrastructural level, identification of the thyrotropic cell appears to be even more hazardous. Its differentiation from gonadotropic cells has been made chiefly on the basis of the diameter of secretory granules (Farquhar and Rinehart, '54. The ultrastructural features that

1 This investigation was supported in part by a grant, HD-03159-03, from the National Institute for Child Health and Human Development. 
may distinguish it from the corticotropic cell are the subject of current debate (Kurosumi and Oota, '66; Kurosumi and Kobayashi, '66; Siperstein and Miller, '70).

Clearly, a more precise method is needed for demonstrating the thyrotropic cell in order to clarify its relationship to other pituitary cell types, the manner in which it responds to alterations in circulating levels of various hormones, and to permit its identification when the cell is small and inactive.

This report is based on a study of the thyrotropic cell in the rat as revealed by the peroxidase-labeled antibody technique (Nakane and Pierce, '67). Nakane ('68, 70) has already described some features of the thyrotropic cell as revealed by this method. However, additional information is needed to verify the specificity of the procedure. The objectives of this investigation were (a) to correlate the presumptive thyrotropic cells as revealed immunochemically with those considered to be thyrotropic cells after histochemical staining, (b) to correlate the structural changes in thyrotropic cells with the known alterations in pituitary thyrotropin content that occur under varied experimental conditions, and (c) to demonstrate the distribution of thyrotropic cells in the gland.

\section{MATERIALS AND METHODS}

Young adult Sprague-Dawley rats were used. Except for observation of the influence of sex on thyrotropic cells, all experiments were carried out on females. Unless otherwise stated the rats were fed ad libitum a diet of Purina Laboratory Chow and were kept in a room maintained at $72^{\circ} \mathrm{F}$ in which 14 hours of light were alternated with ten hours of darkness. The animals were decapitated while under light sodium amytal anesthesia after which their hypophyses were excised, fixed in Bouin's fluid, embedded in paraffin, and sectioned at $3 \mu$ on either a frontal or transverse (dorsoventral) plane.

Immunochemical staining. For immunochemical staining the procedure of Nakane and Pierce ('67) was followed, with 3,3'-diaminobenzidine (DAB) and $\alpha$-naphthol being used as substrates for peroxidase. The sections incubated in a-naphthol were stained subsequently with pyronin. An antiserum to human thyrotropin (anti-TSH) supplied by Dr. William D. Odell was utilized for staining the thyrotropic cell. Since the anti-TSH contained antibodies to luteinizing hormone ( $\mathrm{LH}$ ) it was employed at high dilution after having been absorbed $(1 / 1 \mathrm{v})$ with human chorionic gonadotropin at a concentration of 10,000 I.U. $/ \mathrm{ml}$.

Several steps were taken in an attempt to verify the specificity of the immunochemical staining procedure for thyrotropin. Absorption of anti-TSH with bovine luteinizing hormone (NIH-LH-B-1, lot 7231), ovine follicle-stimulating hormone (NIH-FSH-S-1), or bovine plasma albumen did not block the effectiveness of anti-TSH in the staining procedure, indicating that staining of presumptive thyrotropic cells was not dependent on the presence of antibodies capable of cross-reacting with these hormones. Absorption of the anti-TSH with human or bovine (Armour, lot 317147) thyrotropins completely neutralized its effectiveness. Absorption with ovine thyrotropin (NIH-TSH-S-1), or a partially purified preparation of rat thyrotropin (provided by A. F. Parlow), prevented the staining of almost all presumptive thyrotropic cells. However, even after anti-TSH had been absorbed previously with human chorionic gonadotropin and was then combined at high dilution with a concentrated solution of rat thyrotropin, a few polygonal cells continued to stain lightly. This observation may suggest that the anti-TSH contained a low titer of antibodies to some other unidentified substance. Because of the small number of such cells, this deficiency in the procedure did not interfere seriously in evaluation of the structure of the thyrotropic cell or the influence of experimental treatments on it.

Control procedures for the staining reaction itself included the following modifications of the peroxidase-labeled antibody procedure which resulted in failure of the thyrotropic cells to stain: incubation of the sections in the peroxidase substrate without prior treatment with antiserum to the hormone or with the gamma-globulinperoxidase conjugate, substitution of normal rabbit serum or antiserum to egg albumen for anti-TSH, and blockade of immunoreactive sites on the hormone anti- 
body when attached to the thyrotropic cell by application of unconjugated anti-rabbit gamma-globulin prior to treatment with conjugated anti-rabbit gamma-globulin.

As additional proof of the specificity of the staining procedure, the double staining immunochemical method (Nakane, '68) was used to demonstrate the thyrotropic cell alongside other cell types in the same section. For this purpose antisera to the following hormones were used as previously described: rat prolactin (Baker et al., '69; Baker, '70); human growth hormone (Baker et al., '69); and porcine corticotropin (Baker et al., '70). Antiserum to ovine $\mathrm{LH}^{2}$ was prepared by G. D. Niswender.

The level of circulating thyroid hormone was modified by several experimental means in order to raise or lower the pituitary content of thyrotropin and thus change the staining capacity of the thyrotropic cell. In experiment one, thyrotropic cells were compared in seven male and seven female adult rats. In experiment two, the effect of ovariectomy was observed in seven rats 54 days after the operation, with seven rats serving as controls. In experiment three, the influence of hypothyrodism was studied in five rats surgically thyroparathyroidectomized and injected with $100 \mu \mathrm{Ci}$ of ${ }^{131} \mathrm{I}$ to destroy remaining fragments of the gland. These thyroidectomized animals were then maintained on a low iodine diet (Nutritional Biochemicals Corp.) for 74 days. The nine control rats were fed laboratory chow. Thyroidectomy prevented a gain in body weight. Hypothyroidism was induced also in experiment four by giving nine rats a $0.1 \%$ solution of 6-propylthiouracil (PTU) as drinking fluid for 53 days. The eight control rats drank tap water.

Since a striking increase occurs in the pituitary thyrotropic content within a few days after cessation of PTU treatment (D'Angelo, '61) the rats of experiment five were divided into three groups. Group one, consisting of six animals, received laboratory chow; the six rats in group two were given $0.1 \%$ PTU mixed with ground laboratory chow for 39 days; the six rats in group three were treated similarly with PTU for 30 days and then given laboratory chow for the final nine days. In experi- ments four and five, administration of PTU suppressed the expected gain in body weight. In experiment six, a hyperthyroid state was induced by injecting seven rats subcutaneously each day with $l$-thyroxine for 76 days, the daily dose being increased from $5 \mu \mathrm{g}$ at the beginning to $45 \mu \mathrm{g}$ on the thirty-sixth day. Seven control animals received a comparable volume of the $0.9 \% \mathrm{NaCl}$ solution used as vehicle. Treatment with thyroxine did not interfere with the gain in body weight.

Histochemistry of the thyrotropic cell. Two procedures were followed to determine the histocherical staining properties of the thyrotropic cell as identified with immunochemical staining. After staining a section immunochemically with a-naphthol-pyronin the stain was removed from the cytoplasm by immersion in ethanol and the section restained with either aldehyde fuchsin and the Masson procedure or with the PAS technique. Comparison of photographs of sections made after each of the staining procedures revealed the reaction of thyrotropic cells to aldehyde fuchsin and PAS. Also, adjacent sections were stained either immunochemically or chemically in order to observe staining of the same cell with the two methods.

Distribution of thyrotropic cells in the gland. For observation of the distribution of thyrotropic cells in the pars distalis, hypophyses from both sexes were cut serially and thyrotropic cells stained immunochemically in sections taken from various levels in the gland. In determining the effect of an experimental procedure on the thyrotropic cell, sections from several representative regions of the gland were studied.

\section{OBSERVATIONS}

\section{Cytology of the thyrotropic cell}

The thyrotropic cell was polyhedral (figs. 2,11) with the main portion of the cell body usually lying within a cell cord somewhat removed from a capillary wall. However, the cell often made contact with the capillary wall by means of one or more

\footnotetext{
2 Although it seems certain that the cells revealed by use of antiserum to LH are the source of this hormone, in our hands they have not yet been differen tiated from those producing FSH. Therefore, for the present we are designating them gonadotropin cells.
} 
cytoplasmic processes. Comparison of cells sectioned through the nucleus revealed a considerable variation in size. Particularly in female rats, some thyrotropic cells were comparable in size to the largest gonadotropic cells (fig. 12); in such instances the thyrotropic cell possessed abundant cytoplasm. The cytoplasmic granules were PAS-positive (fig. 4) and colored intensely with aldehyde fuchsin (fig. 6) and with immunochemical staining (fig. 9). Frequently, the cytoplasm was unusually dense in the Golgi region and in the perinuclear zone. In such cases the peripheral cytoplasm was often vacuolated or contained fine granules surrounded by clear canals (fig. 10).

Distribution of thyrotropic cells in the gland. As Nakane ('68) and others before him have noted, thyrotropic cells were often aggregated in clusters (fig. 3 ). In hypophyses of female rats (fig. 8), they were most numerous centromedially and ventrally in the lateral lobes of the pars distalis, and in the median bridge of pars distalis lying beneath the pars intermedia. The concentration of thyrotropic cells in these areas extended into the caudal portion of the gland. The number of thyrotropic cells was far less in the dorsocephalic region. In some glands, the number of cells in the right and left lobes differed greatly but technical factors could not always be ruled out as influencing this appearance. No significant difference was observed in the intraglandular distribution of thyrotropic cells between the sexes (figs. $7,8 \mathrm{c})$.

Differentiation of thyrotropic cells from other cell type's. Double-staining with the immunochemical procedure showed that thyrotropic cells could be delineated sharply from prolactin cells (fig. 9), cortitropic cells (fig. 10), growth hormone cells fig. 11), and gonadotropic cells (fig. 12). These distinctions were made on the basis of color, size, morphology and distribution. In no case were reactions for more than one antibody observed in the same cell.

As compared with thyrotropic cells, prolactin cells were generally smaller, with flatter or more concave sides; they were more generally distributed and more numerous (Baker et al., '69). Corticotropic cells were smaller on the average, more stellate, and possessed long cytoplasmic processes which constituted a greater proportion of the cell volume; likewise their distribution through the gland was more uniform (Baker, '70; Baker et al., '70). As compared with thyrotropic cells, growth hormone cells were more ovoid, smaller, possessed a more uniformly dense cytoplasm and were almost never vacuolated. The incidence and size of growth hormone cells were influenced by sex in contrast to the minor influence of sex on thyrotropic cells. Growth hormone cells were far more numerous and widely distributed through the gland (Baker et al. '69). Gonadotropic cells tended to be more spherical than thyrotropic cells and were uniquely different in distribution; they were most numerous in the dorsocephalic region near the pars intermedia.

\section{Experimental modification of the thyrotropic cell}

In the subsequent description of structural alterations induced in thyrotropic cells by a persistent elevation or depression in the level of circulating thyroid hormone, primary consideration is given to the intensity of the stain that could be developed with the peroxidase-labeled antibody procedure utilized with anti-TSH, as well as to the size and number of the cells giving the reaction. From such observations broad inferences may be drawn regarding the amount of thyrotropin contained within the gland.

Sex. Thyrotropic cells were not counted but comparison of sections taken from sequential zones through the hypophysis showed that the apparent number of thyrotropic cells was similar in the sexes (figs. $7,8 \mathrm{c}$ ). However, in five of seven pairs of rats, thyrotropic cells seemed to attain a larger size and stain more intensely in female than in male rats. Because of the variable distribution of thyrotropic cells in the gland and the wide range in their size, this difference must remain somewhat equivocal until more precise data are obtained.

Ovariectomy. Following ovariectomy no consistent changes in number and size of thyrotropic cells were observed. Although many unstained gonadotropic cells contained "castration vacuoles," no vacuoles 
of this type were observed in any thyrotropic cells.

Treatment with propylthiouracil. Under the conditions of experiment four the number of cells which stained well following application of anti-TSH was reduced sharply by treatment with PTU (figs. 13, 14). Although a few large, well-stained cells remained, they were smaller than the thyrotropic cells of control rats. Also, these few cells might not be thyrotropic cells since some antibodies could not be absorbed from the anti-TSH with rat thyrotropin in control procedures. Thus, the impressive fall in immunoreactive thyrotropin indicates that the amount of stored thyrotropin was reduced by administration of propylthiouracil.

Rebound after propylthiouracil treatment. After thyrotropic cells had lost their immunochemical stainability due to treatment with PTU for 30 days, withdrawal of the drug increased the staining reaction in the cytoplasm of many thyrotropic cells within nine days (fig. 17). This was a general response and seemed to involve all thyrotropic cells that could be identified. Apparently they had multiplied during the period of PTU treatment.

Thyroidectomy. As after treatment with PTU, the number of intensely stained thyrotropic cells was much lower and most of them were smaller in thyroidectomized rats than in their controls (figs. 13, 15). The overall reduced capacity of the gland to stain immunochemically with anti-TSH indicated that the glandular thyrotropic content was depressed by thyroidectomy.

Administration of thyroxine. Longterm administration of thyroxine at high dosage caused a striking regression of thyrotropic cells; in all of the five rats so treated their identification was difficult or impossible (fig. 16).

\section{DISCUSSION}

\section{Specificity of the staining procedure} for thyrotropic cells

Verification of the specificity of the peroxidase-labeled antibody procedure for demonstration of thyrotropic cells in the rat is of primary importance. Interference by the activity of peroxidase intrinsic to hypophyseal parenchymal cells did not occur since no staining developed during incubation in DAB if no antibodies had been applied to the pituitary section. In addition, the following several lines of evidence support the conclusion that the thyrotropic cell has been demonstrated.

Immunological evidence. Because of the chemical similarities of thyrotropin, $\mathrm{LH}$ and FSH, possible contamination with these hormones in the thyrotropin preparation used as the original antigen is a pertinent consideration. Dr. W. D. Odell (personal communication) has observed that the anti-TSH provided us contains antibodies to LH. When applied to sections at low dilution in the peroxidase-labeled antibody procedure, a second population of cells was lightly stained. It was assumed that these cells belonged to the gonadotropic class (fig. 1). However, interference from coupling of antibodies to gonadotropic cells was avoided by dilution of the antiserum and by prior absorption of the anti-TSH with human chorionic gonadotropin (fig. 2). Absorption of anti-TSH with numerous gonadotropic preparations including bovine $\mathrm{LH}$ and ovine FSH did not interfere with its effectiveness in the staining of thyrotropic cells. Indeed, following prior absorption of anti-TSH with $\mathrm{LH}$ the staining reaction of ten seemed to be intensified. The prevention of immunochemical staining of thyrotropic cells by prior absorption of anti-TSH with human, bovine, ovine or murine thyrotropins indicates that the procedure is specific.

Available information about the chemical and immunochemical properties of mammalian thyrotropins suggests the rationality of using antisera to human thyrotropin with peroxidase-labeled antibody for demonstration of thyrotropic cells in the rat and other lower mammals. Although the chemical structure of rat thyrotropin is unknown, recent studies attest to the chemical (Shome, Brown, Howard and Pierce, '68) and immunological (Shome, Parlow, Ramirez, Elrick and Pierce, '68) similarities of human, bovine and porcine thyrotropins. Thus, a considerable structural uniformity may exist among the mammalian thyrotropic hormones. With respect to the interrelationship of bovine thyrotropin and $\mathrm{LH}$, since the CI subunit of $\mathrm{LH}$ is structurally similar to the $a$-subunit of thyrotropin, and antiserum to the 
former reacts with the complete thyrotropic molecule (Liao et al., '69), one would expect that the two hormones might be produced by a single cell. However, since immunological cross-reaction does not occur between the complete hormones, the supposition is strengthened that they may be secreted by different cells.

Immunochemical double staining of thyrotropic cells and other cell types. When sections of the hypophysis were stained for demonstration of thyrotropic cells alongside each of the other cell types, it was shown that thyrotropic cells can be distinguished clearly from the acidophilic types, namely, growth hormone cells and prolactin cells.

Differentiation of thyrotropic from corticotropic cells is of special significance because of earlier findings suggesting that corticotropin is produced by an aldehyde fuchsin-positive cell (Kief, '56) and because the presumptive thyrotropic cell exhibits unique cytological changes under experimental conditions which cause an enhanced secretion of corticotropin. Thus, Halmi ('50) observed an increase in number and enlargement of aldehyde fuchsinpositive cells in semi-adrenalectomized rats exposed to cold, a drop in their percentage incidence in acute stress and after thyroidectomy, as well as a failure to change after castration. Since these alterations seemed to parallel the expected modifications in corticotropic content of the gland as known at that time, he concluded that the aldehyde fuchsin-positive cells should be considered as a possible source of corticotropin. Our previous demonstration (Baker et al., '70) that many corticotropic cells of the rat are aldehyde fuchsin-positive lends credence to Halmi's suggestion. It is now indicated that aldehyde fuchsin should be regarded as a delineator of both corticotropic and thyrotropic cells in the rat but that these are in fact distinct cell types.

Differentiation of the cell types which secrete the glycoprotein hormones remains a problem that requires more extensive investigation. The presumptive $\mathrm{LH}$ cell as demonstrated in this study with antiserum to ovine LH is large, usually ovoid, and has a unique distribution, being most nu- merous in the dorsocephalic "sex zone" and along the pars intermedia. With respect to shape and size of the cell, these observations agree with those of Monroe and Midgley ('69) who used immunofluorescence with antibodies to human chorionic gonadotropin to demonstrate LH cells in the rat. Thus, on the basis of differences in cytology and distribution and the immunochemical differentiation of both types in a single section, it seems certain that thyrotropic and presumptive LH cells as illustrated here are distinctive types.

With respect to the FSH cell we have not yet acquired adequate evidence to show that it is different from the LH cell on the one hand and from the thyrotropic cell on the other. The rat FSH cell has been demonstrated with immunofluorescence by Rennels ('63) while Nakane ('70), on the basis of immunochemical evidence, concluded that FSH and LH are produced by a single cell type. Our present inability to make a clear distinction between the origins of thyrotropin and FSH is reminiscent of suggestions by others that thyrotropic and gonadotropic cells may be identical (e.g., Yoshimura and Ishikawa, '69).

\section{Intraglandular distribution of thyrotropic cells}

Purves and Griesbach ('51a) studied the distribution of thyrotropic cells as revealed by staining with PAS. They concluded that thyrotropic cells are aggregated in the "central region throughout the whole anterior lobe," and are infrequent elsewhere. Our preparations show that thyrotropic cells are concentrated in the centromedian zone of the lateral lobes of the pars distalis and that they are common ventrally in a bridge of pars distalis beneath the pars intermedia. Further, the cells extend far caudally in the gland. As Purves and Griesbach ('51a) pointed out, thyrotropic cells are rare in the cephalic and dorsal regions and do not accumulate around the larger blood vessels of that region as is characteristic of gonadotropic cells. Thus, the conclusions of all workers regarding intraglandular distribution of thyrotropic cells as observed with immunochemical and histological staining are in essential agreement. 
Correlation of thyrotropic cell cytology with pituitary hormone content

The following comparisons are made between changes in size and stainability of thyrotropic cells under different experimental conditions and the previously demonstrated alterations in thyrotropic content of the gland, in order to provide additional evidence regarding the specificity of the procedure.

Sex. D'Angelo ('68) observed a somewhat higher concentration of thyrotropin in hypophyses of adult female rats than in males although the difference was not statistically significant. However, the difference in total content was still greater because the hypophyses were heavier in females. In our study, the size of thyrotropic cells seemed slightly greater in the female, so that the higher amount of thyrotropin observed by D'Angelo in female hypophyses might be accounted for in this way. Without more precise information, a definitive comparison cannot be made between the sexes with respect to the cytology of thyrotropic cells and pituitary hormone content. Nevertheless, the trend with respect to both features favors the female.

The influence of female sex hormone. Estrogen has a considerable influence on the thyrotropic content of the rat hypophysis. A decline occurs in female rats with advancing age (D'Angelo, '66), and three weeks or one year after ovariectomy both the concentration and total amount of thyrotropin are reduced in the pituitary gland (D'Angelo, '66). On the other hand, although administration of estrogen does not affect thyrotropic pituitary content in thyroidectomized male rats, it causes a decrease when given to intact males (Amesbury et al., '65) and within a re. stricted dose range in female rats also (D'Angelo, '68).

In view of the severe depletion of pituitary thyrotropin reported to follow ovariec.tomy, a great change was expected in the thyrotropic cells. This did not occur, with changes in number, size and staining capacity being quite variable from one ovariectomized rat to another and no clear pattern of difference emerging between them and nonoperated controls.

Alteration in the level of circulating thyroid hormone. A few investigators (Zeck- wer, '36; Gordon et al., '45; Sinha and Meites, '65; Bakke and Lawrence, '64) have reported that the hypophyseal thyrotropic content rises during thyroid deficiency. However, most evidence indicates that an impressive decline occurs after excision of the thyroid gland and/or its destruction by administration of ${ }^{131} \mathrm{I}$ (Turner and Cupps, '40; Mess, '58; Contopoulos et al., '58; Salaman, '64; van Rees, '66), or after treatment with a goitrogenic drug (D'Angelo, '61). The fall in thyrotropin may be severe; in one of D'Angelo's ('69) experiments only about $4 \%$ of the normal amount remained in the hypophyses of rats maintained on PTU for 270 days. Depletion of pituitary thyrotropin in the hypothyroid rat seems to be assured if several weeks intervene between the times of thyroid inactivation and analysis of pituitary thyrotropin and if, according to D'Angelo ('69), the following additional experimental criteria are met: all thyroid fragments are destroyed, thyroid-like substances are eliminated from the diet, and an effective level of the antithyroid drug is maintained in rats made hypothyroid by this means.

In our experiments all of the criteria outlined by D'Angelo for maintaining a state of severe hypothyroidism were probably met. Hence, it may be expected that in accord with his observations the amount of thyrotropin was reduced sharply in the hypophysis. It follows that the sparsity of cells that stained immunochemically for thyrotropin in both thyroidectomized ${ }^{131} \mathrm{I}$ irradiated and in PTU-treated rats is to be expected. The presence of some thyrotropin in the hypophysis of hypothyroid rats may be accounted for in part by scattered cells which seem to have been unaffected by the absence of thyroid hormone, and by the probability that some hormone was lost from the cells during fixation and embedding.

The great resurgence in pituitary storage of thyrotropin in rats after cessation of propylthiouracil treatment (D'Angelo, '69) is correlated directly with an impressive recrudescence of the cells that react strongly to immunochemical staining for the hormone.

As in hypothyroidism, elevation of the level of circulating thyroid hormone by 
administration of a high dose of thyroxine also causes a fall in pituitary thyrotropic content to $2-3 \%$ of the normal level (D'Angelo, '58). In accord with this condition we found thyrotropic cells to be so depleted of hormone that they could no longer be stained immunochemically.

It may be concluded from the above correlations that a parallelism exists between pituitary thyrotropic content and stainability of the gland with the peroxidaselabeled antibody procedure. Evidence of this nature tends to verify the specificity of the immunochemical procedure for demonstration of thyrotropic cells. Among the experimental conditions examined, only in the case of ovariectomy was such a correlation not established.

\section{Comparative usefulness of aldehyde fuchsin, PAS and peroxidase- labeled antibody for staining thyrotropic cells}

As used in this study the peroxidaselabeled antibody procedure appears to offer only slightly more sensitivity for detection of the thyrotropic cell than does staining with aldehyde fuchsin or PAS. In almost every experimental situation used in this study for modification of pituitary thyrotropic content, the changes we observed by immunochemical staining of thyrotropic cells have been reported previously by other workers who utilized aldehyde fuchsin and/or the PAS procedure. These effects include depletion of aldehyde fuchsin-positive granulation following administration of thyroxine (Purves and Greisbach, '51c; D'Angelo, '58), thyroidectomy (Halmi, '50; Purves and Griesbach, '51c; D'Angelo, '63), or treatment with goitrogens, as well as restoration of aldehyde fuchsin-positive granulation during the rebound period after cessation of PTU treatment. In addition, vacuolated thyroidectomy cells do not stain significantly with aldehyde fuchsin (D'Angelo, '63) and, when fully developed, show no response to immunochemical staining with anti-TSH (Baker et al., unpublished). Similarly, after cessation of thiouracil treatment, these vacuolated cells quickly recover their aldehyde fuchsin-positive granulation (D'Angelo, '61); also stain intensely with the immunochemical procedure. Since
Baker et al. ('70) have shown that many corticotropic cells in the rat are also aldehyde fuchsin-positive, a major advantage provided by immunochemical staining lies in its capacity to differentiate thyrotropic from corticotropic cells. Similarly, immunochemical staining as used here permits clear differentiation of thyrotropic cells from a class of gonadotropic cells which appear to secrete LH. In our hands the cellular origin for $\mathrm{FSH}$ and its relation to the thyrotropic cell remain to be demonstrated.

\section{ACKNOWLEDGMENTS}

The authors thank the following persons for providing the preparations indicated: Dr. W. D. Odell, antiserum to human thyrotropin; Dr. A. F. Parlow, rat thyrotropin; and Dr. A. R. Midgley, Jr., for numerous other antisera.

\section{LITERATURE CITED}

Amesbury, O. F., A. N. Contopoulos and A. A. Koneff 1965 Effects of oestrogen on pituitary function in the thyroidectomized rat. Acta Endocr., 48: 355-368.

Baker, B. L. 1970 Studies on hormone localization with emphasis on the hypopyhsis. J. Histochem. Cytochem., 18: 1-8.

Baker, B. L., A. R. Midgley, Jr., B. E. Gersten and Y. Y. Yu 1969 Differentiation of growth hormone- and prolactin-containing acidophils with peroxidase-labeled antibody. Anat. Rec., 164: 163-172.

Baker, B. L., S. Pek, A. R. Mídgley, Jr. and B. E. Gersten 1970 Identification of the corticotropin cell in rat hypophyses with peroxidaselabeled antibody. Anat. Rec., 166: 557-568.

Bakke, J. L., and N. Lawrence 1964 Influence of propylthiouracil and thyroxine on synthesis and secretion of thyroid stimulating hormone in the hypothyroid rat. Acta Endocr., 46: 111123.

Contopoulos, A. N., M. E. Simpson and A. A. Koneff 1958 Pituitary function in the thyroidectomized rat. Endocrinology, 63: 642-653.

D'Angelo, S. A. 1958 Role of the hypothalamus in pituitary-thyroid interplay. J. Endocr., 17: 286-299.

- 1961 TSH rebound phenomenon in the rat adenohypophysis. Endocrinology, 69: 834843. in the rodent. In: Cytologie de l'Adénohypophyse. J. Benoit and C. Da Lage, eds. Editions du Centre National de la Recherche Scientifique, Paris, pp. 149-162.

- 1966 A comparative study of TSH and FSH secretion in rat and guinea pig: effects of gonadectomy and goitrogens. Endocrinology, 78: 1230-1237. 
1968 Simultaneous effects of estradiol on TSH secretion and adrenocortical function in male and female rats. Endocrinology, 82: 1035-1041.

1035 Action of target gland hormones on pituitary TSH rebound: validation of the threshold hypothesis of TSH secretion. Endocrinology, 84: 632-640.

Dhom, G. 1963 Fortschritte der Histophysiologie des Hypophysenvorderlappens. Klin. Wschr., 41: 1117-1125.

Farquhar, M. G., and J. F. Rinehart 1954 Cytologic alterations in the anterior pituitary gland following thyroidectomy: an electron microscope study. Endocrinology, 55: 857-876.

Goluboff, L. G., M. E. MacRae, C. Ezrin and E. A. Sellers 1970 Autoradiography of tritiated thymidine labelled anterior pituitary cells in propylthiouracil treated rats. Presented at the 52nd meeting, The Endocrine Society, 1970.

Gordon, A. S., E. D. Goldsmith and H. A. Charipper 1945 Thyrotrophic hormone content of the blood sera and pituitary glands of thiourea-, sulfadiazine-treated and thyroidectomized rats. Endocrinology, 36: 53-61.

Halmi, N. S. 1950 Two types of basophils in the anterior pituitary of the rat and their respective cytophysiological significance. Endocrinology, 47: 289-299.

1952 Two types of basophils in the rat pituitary: "thyrotrophs" and "gonadotrophs" vs. beta and delta cells. Endocrinology, 50: 140142.

Kief, H. 1956 Experimentelle Untersuchungen über die zelluläre Bildungsstätte des ACTH. Beitr. path. Anat., 116: 541-573.

Kurosumi, K., and Y. Kobayashi 1966 Corticotrophs in the anterior pituitary glands of normal and adrenalectomized rats as revealed by electron microscopy. Endocrinology, 78: 745758.

Kurosumi, K., and Y. Oota 1966 Corticotrophs in the anterior pituitary glands of gonadectomized and thyroidectomized rats as revealed by electron microscopy. Endocrinology, 79: 808-814.

Liao, T.-H., G. Hennen, S. M. Howard, B. Shome and J. C. Pierce 1969 Bovine thyrotropin. Countercurrent distribution and a comparison with the isolated subunits of luteinizing hormone. J. Biol. Chem., 244: 6458-6467.

Mess, B. 1958 Veränderungen des Gehaltes der Hypophyse an thyreotropem Hormon nach Thyreoidektomie und gleichzeitiger Läsion der Nuclei habenulae. Endokrinologie, 35: 296-301.

Monroe, S. E., and A. R. Midgley, Jr. 1969 Immunofluorescent localization of rat luteinizing hormone. Proc. Soc. Exp. Biol. Med., 130: $151-156$

Nakane, P. K. 1968 Simultaneous localization of multiple tissue antigens using the peroxidase-labeled antibody method: A study on pituitary glands of the rat. J. Histochem. Cytochem., 16: $557-560$
1970 Classifications of anterior pituitary cell types with immunoenzyme histochemistry. J. Histochem. Cytochem., 18: 9-20.

Nakane, P. K., and G. B. Pierce, Jr. 1967 Enzyme-labeled antibodies for the light and electron microscopic localization of tissue antigens J. Cell Biol., 33; 307-318.

Purves, H. D., and W. E. Griesbach 1951a The site of thyrotrophin and gonadotrophin production in the rat pituitary studied by McManusHotchkiss staining for glycoprotein. Endocrin. ology, 49: 244-264.

- 1951b Specific staining of the thyrotrophic cells of the rat pituitary by the Gomori stain. Endocrinology, 49: 427-428.

- 1951c The significance of the Gomori staining of the basophils of the rat pituitary. Endocrinology, 49: 652-662.

Rennels, E. G. 1963 Gonadotrophic cells of rat hypophysis. In: Cytologie de l'Adénohypophyse. $\mathrm{J}$. Benoit and C. Da Lage, eds. Editions du Centre National de la Recherche Scientifique, Paris, pp. 201-214.

Salaman, D. F. 1964 Thyrotrophic hormone in the plasma and anterior pituitary of the thyroidectomized rat. J. Endocr, 29: 283-291.

Shome, B., D. M. Brown, S. M. Howard and J. G. Pierce 1968 Bovine, human and porcine thyrotropins: molecular weights, amino- and carboxyl-terminal studies. Arch. Biochem. Biophys., 126: $456-468$.

Shome, B., A. F. Parlow, V. D. Ramirez, H. Elrick and J. B. Pierce 1968 Human and porcine thyrotropins: a comparison of electrophoretic and immunological properties with the bovine hormone. Arch. Biochem. Biophys., 103: 444455.

Sinha, D., and J. Meites 1965 Effects of thyroidectomy and thyroxine on hypothalamic concentration of "thyrotropin releasing factor" and pituitary content of thyrotropin in rats. Neuroendocrinology, $1 ; 4-14$.

Siperstein, E. R., and K. J. Miller 1970 Further cytophysiologic evidence for the identity of the cells that produce adrenocorticotrophic hormone. Endocrinology, 86: 451-486.

Turner, C. W., and P. T. Cupps 1940 The effect of certain experimental conditions upon the thyrotropic hormone content of the albino rat. Endocrinology, 26: 1042-1047.

van Rees, G. P. 1966 The effect of triiodothyronine and thyroxine on thyrotrophin levels in the anterior pituitary gland and blood serum of thyroidectomized rats. Acta Endocr., 51: 619624.

Yoshimura, F., and H. Ishikawa 1969 Identification of the thyrotrophs with the gonadotrophs in the anterior pituitaries of thyroidectomized rats. Endocr. Jap., 16: 69-85.

Zeckwer, I. T. 1936 Thyrotropic effect of pituitaries from cretin rats. Am. J. Physiol., 117: 518-524. 
PLATE 1

EXPLANATION OF FIGURES

1 Hypophysis of a female rat stained immunochemically for thyrotropic cells with anti-TSH used at high concentration and without prior absorption with human chorionic gonadotropin. Both thyrotropic (T) and gonadotropic (G) cells are stained. DAB. $\times 600$.

2 Section from the same hypophysis as illustrated in figure 1. Stained immunochemically using anti-TSH after dilution and prior absorption with human chorionic gonadotropin. Gonadotropic cells no longer stain. $T$, thyrotropic cells. DAB. $\times 600$.

3 Hypophysis of a female rat stained immunochemically with anti-TSH. A cluster of thyrotropic cells $(\mathrm{T})$ is illustrated, $a-\mathrm{Naphthol}$-pyronin. $\times 1000$.

4 Same field as illustrated in figure 3. After being stained immunochemically, the section was decolorized and restained with PAS, showing that the cytoplasm of the presumptive thyrotropic cells is PAS-positive. $\times 1000$.

5 Hypophysis of a female rat stained immunochemically with anti-TSH. Three thyrotropic cells $(\mathrm{T})$ are illustrated. a-Naphthol-pyronin. $\times 1000$.

6 Same field as illustrated in figure 5. After being stained immunochemically, the section was decolorized and restained with aldehyde fuchsin and the Masson procedure, showing that thyrotropic cells $(T)$ are aldehyde fuchsin-positive $\times 1000$

7 A view of part of a dorsoventral section through the middle of the hypophysis of a male rat showing the distribution of thyrotropic cells (black dots) in the pars distalis (P.D.) (plane of section comparable to that in figure $8 \mathrm{c}$ of the female). Thyrotropic cells appear chiefly in the centromedial portions of the lateral lobes of the pars distalis and ventral to the pars intermedia. Stained immunochemically with DAB as substrate. P. I., pars intermedia; P. N., pars nervosa. $\times 39$. 

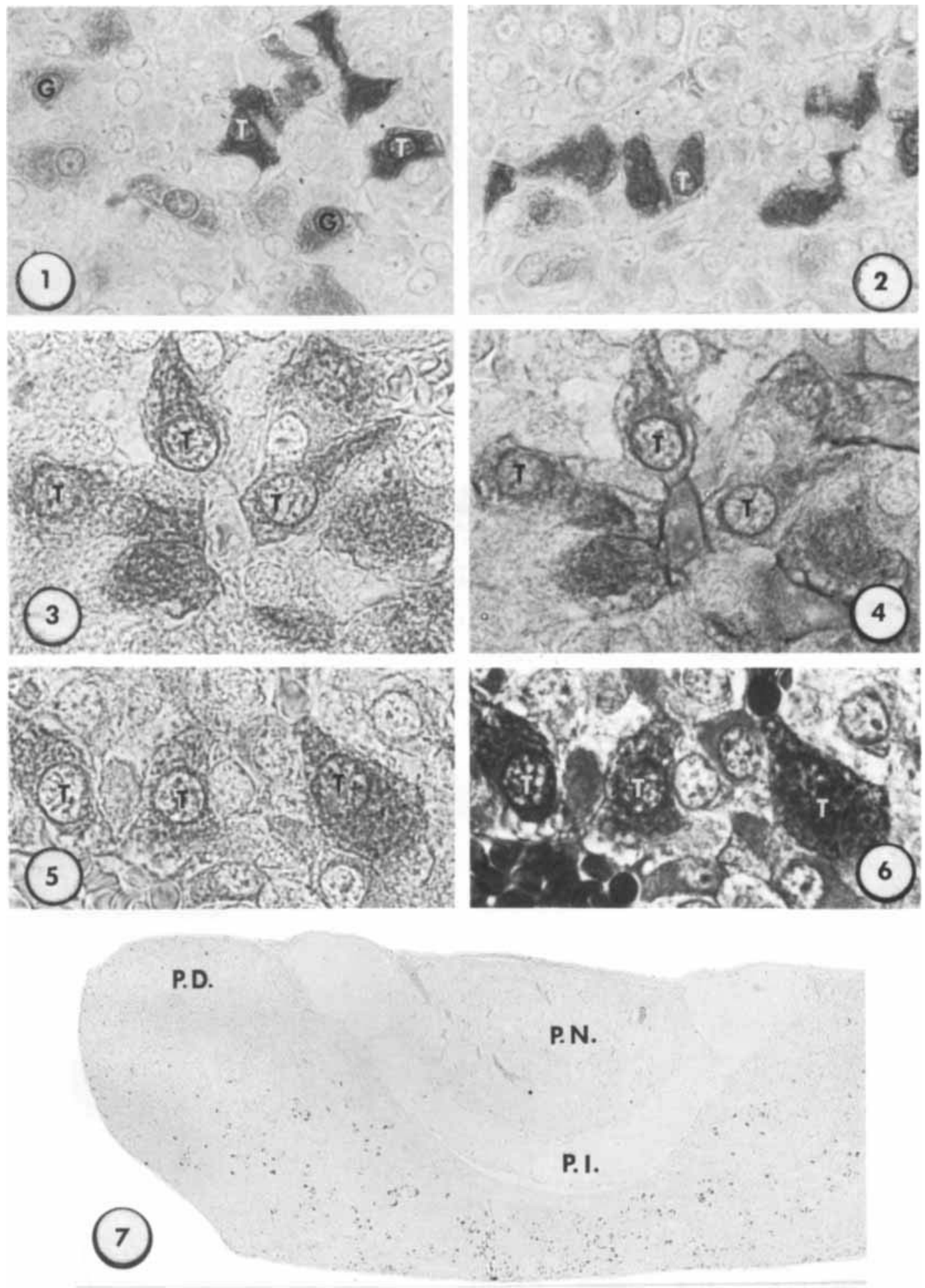
PLATE 2

EXPLANATION OF FIGURE

8 All photomicrographs represent portions of dorsoventral sections through the hypophysis of a female rat. They are taken from cephalic (a) to caudal (e) regions of the gland. Thyrotropic cells appear as black dots in the pars distalis (P.D.). They are scarce in the cephalic sections ( $a$ and $b$ ). In the middle section (c) thyrotropic cells are numerous in the centromedial region of the lateral lobes of the pars distalis and along the ventral zone. They are scarce in the dorsolateral areas of the lateral lobes and in a narrow zone along the pars intermedia (P.I.). Thyrotropic cells remain numerous into the caudal ( $d$ and $e$ ) regions of the gland.

As compared with the male hypophysis (fig. 7), thyrotropic cells appear larger and possibly somewhat more numerous in the female (c).

Immunochemically stained; DAB as substrate. P. N., pars nervosa. $\times 39$. 

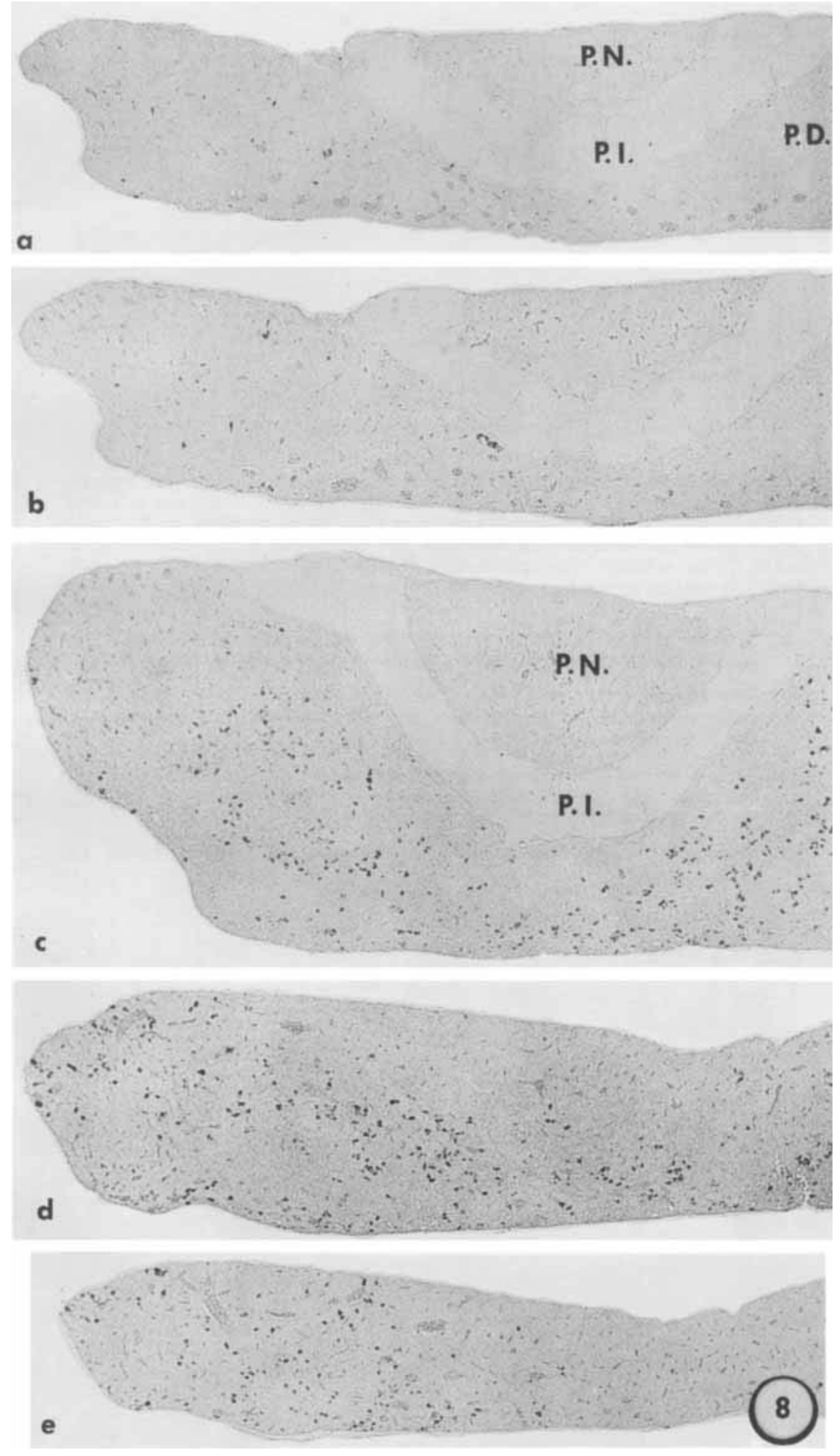
PLATE 3

EXPLANATION OF FIGURES

All photomicrographs on this plate represent sections of female hypophyses which were stained immunochemically for the thyrotropic cell and, in each case, for one other cell type. For the double-staining method DAB was used as the substrate for one cell type and a-naphthol-pyronin for the other. Thus, one cell type appeared gold with DAB and the other lavender with $c$-naphthol-pyronin. $\times 1000$.

9 Thyrotropic cells (gold) and prolactin cells (lavender). Observe the coarse granulation and dense cytoplasm of the thyrotropic cells.

10 Thyrotropic cells (gold) and three corticotropic cells (lavender). Observe the peripheral vacuolation and dense perinuclear cytoplasm in the lower thyrotropic cells.

11 Thyrotropic cells (gold) and growth hormone cells (lavender). Growth hormone cells are small and tend to be ovoid in contrast with the larger stellate thyrotropic cell near the center.

12 Thyrotropic cells (gold) and gonadotropic cells (presumptive LH cells) (lavender). 
THE THYROTROPIC CELL

PLATE 3

Burton L. Baker and Ya-Yen Yu

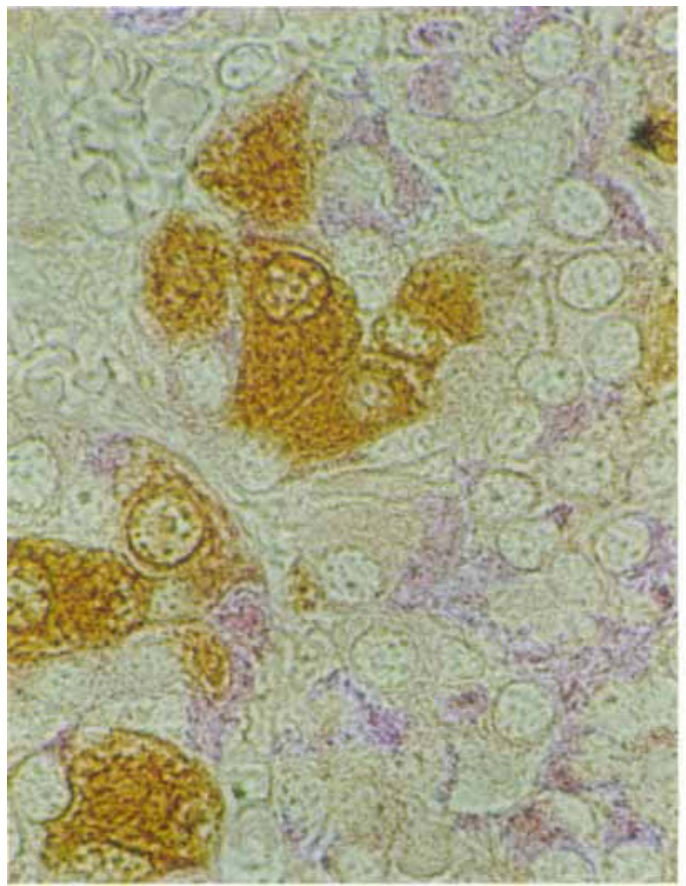

9

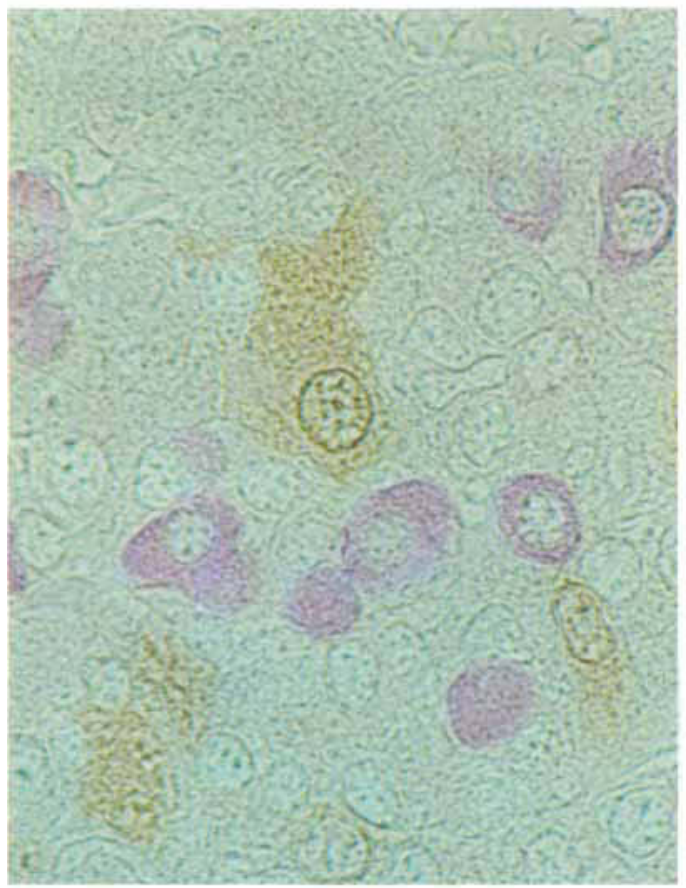

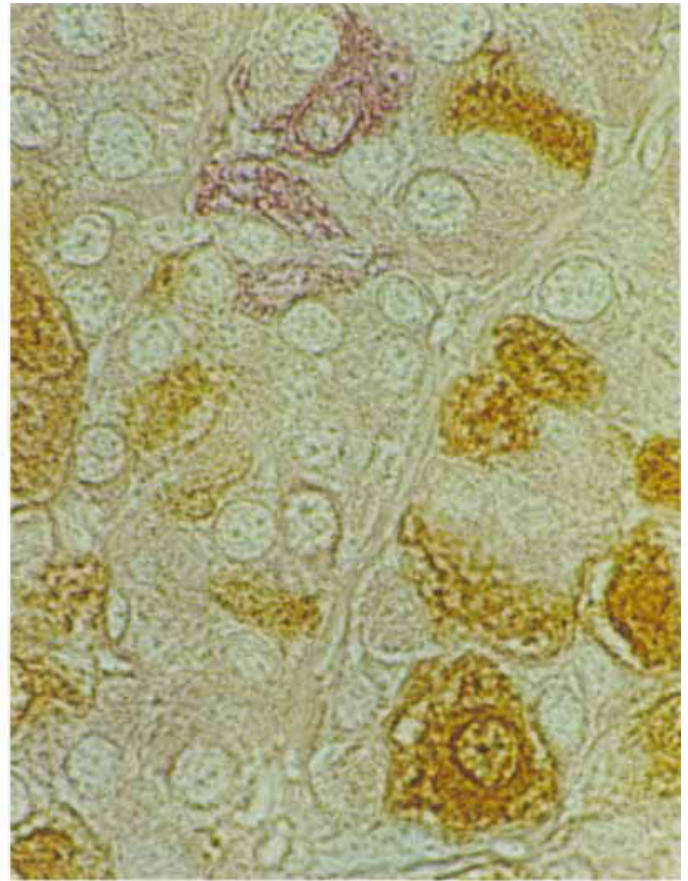

10

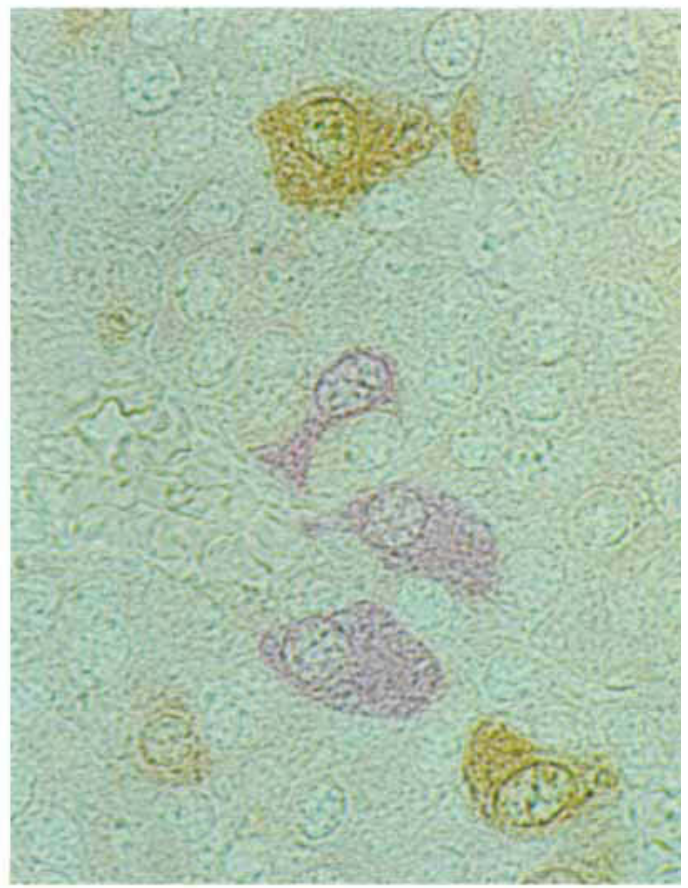

12 


\section{PLATE 4}

\section{EXPLANATION OF FIGURES}

This plate demonstrates the effect of various experimental procedures on the thyrotropic cell in the hypophyses of female rats. All sections represented were stained immunochemically with DAB being used as substrate. All photographs were made in the centromedial area of the lateral lobe of the pars distalis. $\times 160$.

13 Hypophysis of a rat which served as a control for those treated with thyroxine. The thyrotropic cells (appearing black) as illustrated in this photograph did not differ significantly from those in the controls of all other experiments. Hence, it may be considered the control picture for figures 14-17.

14 Hypophysis of a rat treated with PTU for 53 days. Almost all thyrotropic cells have lost their capacity to stain immunochemically. A few small cells remained which were stained. These cells might not be thyrotropic cells but may appear due to the presence of antibodies in anti-TSH which could not be absorbed with rat thyrotropin.

15 Hypophysis of a rat 74 days after thyroparathyroidectomy and administration of 131I. Most thyrotropic cells have lost their staining capacity but, as in glands from rats treated with PTU (fig. 14), a few stained cells may still be identified.

16 Hypophysis of a rat treated with thyroxine for 76 days. Thyrotropic cells no longer stain with sufficient intensity to permit accurate identification.

17 Hypophysis of a rat given PTU for 30 days which resulted in failure of thyrotropic cells to stain (fig. 14). At this time treatment with PTU was stopped. During the subsequent nine days, stainability of thyrotropic cells was restored and apparently their number was increased above normal (cf., fig. 13). 


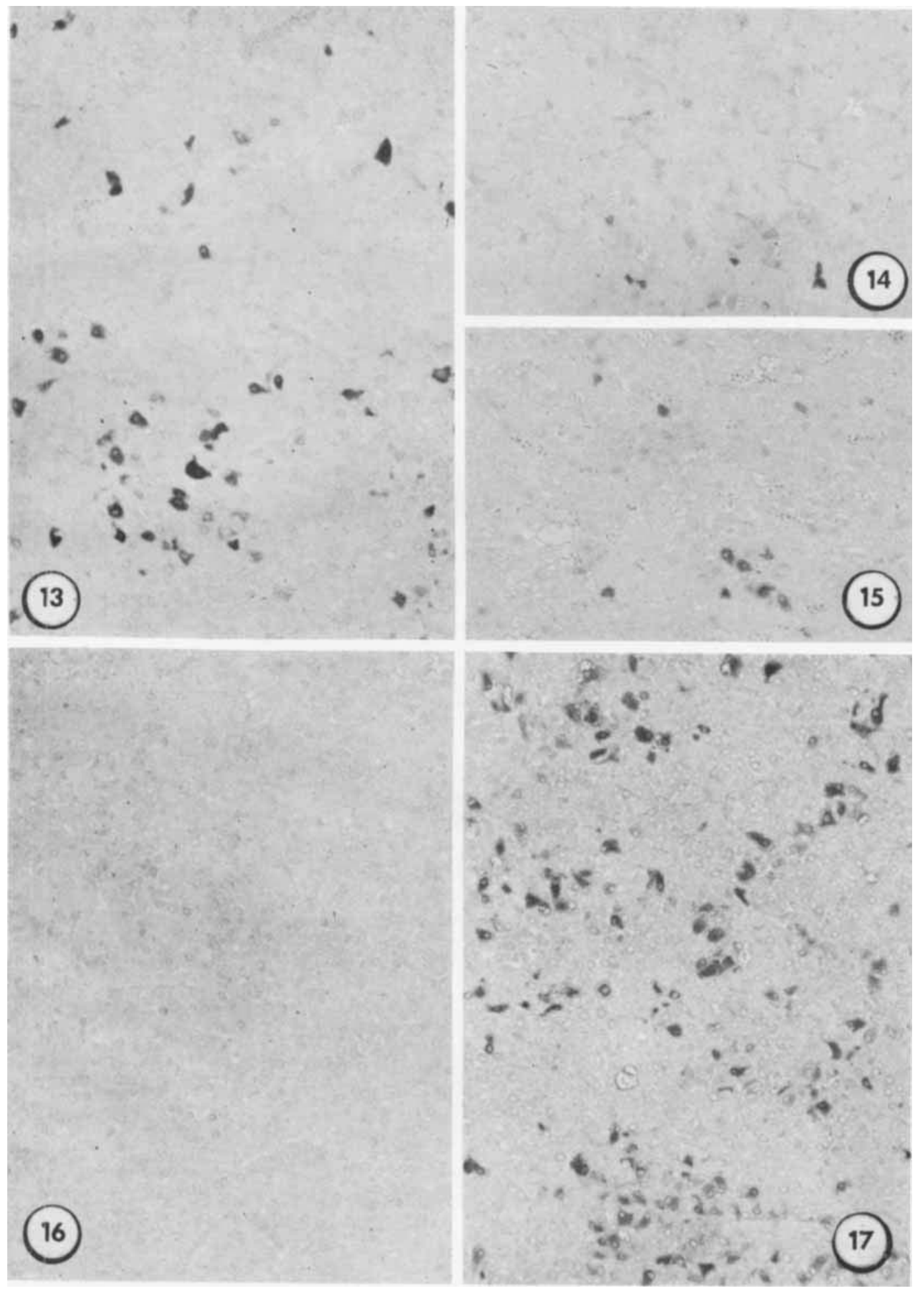

